\title{
Isolation and partial characterization of rat sperm tail fibrous sheath proteins and comparison with rabbit and human spermatozoa using a polyclonal antiserum
}

\author{
Y. H. Kim ${ }^{1}$, J. R. McFarlane ${ }^{1 *}$, G. Almahbobi ${ }^{1}$, P. G. Stanton ${ }^{2}$, \\ P. D. Temple-Smith ${ }^{3}$ and D. M. de Kretser ${ }^{1}$ \\ ${ }^{1}$ Institute of Reproduction and Development; ${ }^{2}$ Department of Biochemistry, and ${ }^{3}$ Department of Anatomy, \\ Monash University, Clayton, Australia 3168
}

\begin{abstract}
Rat sperm tail fibrous sheath was isolated using mechanical and chemical dissection methods from spermatozoa collected from the cauda epididymis. The procedures used to isolate the fibrous sheath were monitored by phase-contrast microscopy and purity was verified by electron microscopy. SDS-PAGE of isolated total fibrous sheath revealed at least 17 bands when stained with Coomassie brilliant blue and 20 bands with silver stain. The most intensely staining proteins, using both staining methods, were a double band at $80-87 \mathrm{kDa}$, and $\mathrm{a}$ band at $28.5 \mathrm{kDa}$, whereas with silver staining, bands at $66.2 \mathrm{kDa}$ and $32.7 \mathrm{kDa}$ were also intensely stained. Electroelution following SDS-PAGE was used to isolate 11 of these proteins (116.4, 87.5, 80.9, 66.2, 57.2, 49.7, 46.8, 37.3, 32.7, 28.5 and $15.5 \mathrm{kDa})$. Amino acid analysis revealed that these proteins were abundant in aspartic and glutamic acid, glycine, serine and leucine, while histidine and phenylalanine were of low abundance. The content of cystine varied widely from $9.4 \%$ to $1.4 \%$. The amino termini of the $80.9 \mathrm{kDa}, 32.7 \mathrm{kDa}$, $28.5 \mathrm{kDa}$ and $15.5 \mathrm{kDa}$ proteins were blocked. Immunofluorescence microscopy demonstrated that a polyclonal antiserum to isolated rat fibrous sheath was localized to the principal piece of the rat, rabbit and human spermatozoa, but in the rabbit it also labelled the equatorial region of the head. Western blotting detected all protein bands in isolated fibrous sheath and a similar range of proteins in the spermatozoa of rat and rabbit. Human sperm proteins of $116 \mathrm{kDa}$ and $80 \mathrm{kDa}$ were immunoreactive in common with other species, and there was only weak crossreactivity with the other proteins. These data suggest the presence of common epitopes in the proteins of all three species.
\end{abstract}

\section{Introduction}

The movement of mammalian spermatozoa depends on their flagellae, which consist of several cytoskeletal components including the axoneme, the outer dense fibres and the fibrous sheath. The fibrous sheath is a component of the principal piece, which begins at the termination of the mid-piece mitochondrial sheath and extends for most of the remaining length of the flagella. The fibrous sheath is composed of two cytoskeletal elements, longitudinal columns and numerous transverse ribs, which surround the outer dense fibres composed of a central medulla and a thin limiting cortex (Fawcett, 1970, 1975; Sapsford et al., 1970). The longitudinal columns, which run in positions equivalent to 3 and 8 of the outer dense fibre system of the mid-piece, are assembled during the early part of spermiogenesis in rats, whereas the transverse ribs arise during the second half of spermiogenesis, and both proceed from distal to proximal in the developing flagellum (Irons and

*Correspondence.

Received 8 November 1994
Clermont, 1982; Oko and Clermont 1989; Clermont et al., 1990).

There have been several studies using antibodies that recognize epitopes on proteins present in mouse fibrous sheath (Sakai et al., 1986), human fibrous sheath (Jassim et al., 1990, 1991; Jassim, 1991) and rat fibrous sheath (Oko, 1988), and a monoclonal antibody that recognizes a $67 \mathrm{kDa}$ antigen in rat, mouse and hamster spermatozoa (Fenderson et al., 1988). It has been reported that two monoclonal antibodies, S69 and S70, recognize the principal piece of the human sperm flagellum (Beecher et al., 1993).

The fibrous sheath is an insoluble keratin-like structure with extensive disulfide linkages (Bedford and Calvin, 1974; O'Brien and Bellve, 1980) and, judged by its morphological, biochemical, physical and immunological features, it is proposed that it is a modified form of the intermediate filament proteins (Eddy, 1988; Eddy et al., 1992; Jassim et al., 1992). The major proteins that compose the rat fibrous sheath are of molecular masses of 75-80, 27.5 and 14.4 kDa (Olson et al., 1976; Oko, 1988) and are highly phosphorylated owing to their high content of serine (Brito ef al., 1989). Comparative studies of the fibrous 
sheath and outer dense fibres by immunochemistry (Oko, 1988) and peptide mapping (Brito et al., 1989) suggest that the $14.4 \mathrm{kDa}$ polypeptide of the fibrous sheath is common to the outer dense fibres, whereas the two larger proteins, $80 \mathrm{kDa}$ and $24 \mathrm{kDa}$, are unrelated to the outer dense fibre proteins. Brito et al. (1989) reported the isolation and amino acid composition of three of the fibrous sheath proteins in rats.

The present study extends our knowledge of the composition of the fibrous sheath by the isolation of additional proteins and by providing the amino acid composition of 11 of its protein components. In addition, the sperm proteins among different species (human, rabbit and rat) were compared using a polyclonal antibody raised against isolated rat fibrous sheath.

\section{Materials and Methods}

\section{Experimental animals}

Spermatozoa were obtained from Sprague-Dawley rats (Central Animal House, Monash University), 90-110 days old, killed by $\mathrm{CO}_{2}$ anaesthesia. These investigations were approved by Monash University Standing Committee on Ethics in Animal Experimentation and conform to the NHMRC/CSIRO/ AAC Code of Practice for the Care and Use of Animals for Experimental Purposes. Rabbit spermatozoa were collected from adult New Zealand white rabbits by artificial vagina and human spermatozoa were provided by the Andrology Department at Monash Medical Centre.

\section{Preparation of rat sperm tails}

The rat cauda epididymides were dissected and spermatozoa released by mincing with razor blades in several drops of $0.05 \mathrm{~mol}$ sodium phosphate buffer $1^{-1}, \mathrm{pH} 7.5,0.15 \mathrm{~mol} \mathrm{NaCl}$ $\mathrm{l}^{-1}$, containing $0.2 \mathrm{mmol}$ phenylmethylsulfonyl fluoride $\mathrm{l}^{-1}$ (PBS-PMSF). The sperm tails were isolated from the heads using the protocol developed by Calvin (1976). The spermatozoa were filtered through $180 \mu \mathrm{m}$ nylon mesh and washed twice in PBS-PMSF at $400 \mathrm{~g}$ for $10 \mathrm{~min}$. Isolated spermatozoa were decapitated by sonication twice (Sonifier model B-30, Branson Sonic Power Co., Shelton, CT) at 30\% output for $30 \mathrm{~s}$ at $4^{\circ} \mathrm{C}$ and, after washing with PBS-PMSF, the decapitated spermatozoa were centrifuged through a sucrose step gradient $(75,70,65 \% \mathrm{w} / \mathrm{v}$ ) at $100000 \mathrm{~g}$ for $80 \mathrm{~min}$ (Beckman SW 28 rotor). The sperm tails, removed from the $65-70 \%$ interface, were suspended in PBS-PMSF, and centrifuged through a sucrose step gradient $65 \%$ and $75 \%(w / v)$ at $100000 \mathrm{~g}$ for $60 \mathrm{~min}$ to increase the purity of sperm tails. Isolated sperm tails from the $65-75 \%$ sucrose interface were washed and centrifuged at $10000 \mathrm{~g}$ for $10 \mathrm{~min}$ (Sorvall SS34 rotor) with PBS-PMSF, and subsequently used for the isolation of the fibrous sheath. Each procedure was verified by phase-contrast microscopy.

\section{Isolation of fibrous sheath}

The procedure used to isolate the fibrous sheath from the sperm tails was a modification of the method of Olson et al.
(1976). The isolated sperm tails were suspended for $15 \mathrm{~min}$ in $50 \mathrm{mmol}$ Tris $-\mathrm{HCl} 1^{-1}, \mathrm{pH} 9.0,2 \%(\mathrm{v} / \mathrm{v})$ Triton $\mathrm{X}-100$ and $5 \mathrm{mmol}$ DTT $1^{-1}$ with gentle shaking at $4^{\circ} \mathrm{C}$; the supernatant was discarded and the procedure repeated. After washing with $50 \mathrm{mmol}$ Tris- $\mathrm{HCl} \mathrm{l} 1^{-1}, \mathrm{pH} 9.0$, containing $0.2 \mathrm{mmol}$ PMSF $\mathrm{I}^{-1}$, the sperm tails were resuspended in $25 \mathrm{mmol}$ Tris- $\mathrm{HCl}$ $\mathrm{l}^{-1}, \mathrm{pH} 8.0,4.5 \mathrm{~mol}$ urea $1^{-1}, 25 \mathrm{mmol}$ DTT $1^{-1}$ and shaken for $5 \mathrm{~h}$ at $4^{\circ} \mathrm{C}$. The resultant insoluble fraction was suspended

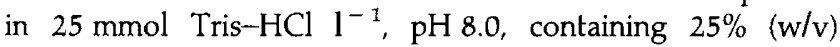
sucrose and centrifuged through a sucrose step gradient comprising $25,50,75 \%(\mathrm{w} / \mathrm{v})$ at $100000 \mathrm{~g}$ for $50 \mathrm{~min}$. The final insoluble fraction was removed from the $50-75 \%$ sucrose interface and washed with $25 \mathrm{mmol}$ Tris $-\mathrm{HCl} \mathrm{I}^{-1}$ at $50000 \mathrm{~g}$ for $20 \mathrm{~min}$. Each step of the procedure was monitored by phase-contrast and electron microscopy.

\section{Preparation of sperm proteins}

Rat, rabbit and human spermatozoa were solubilized in $4.5 \mathrm{~mol}$ urea $\mathrm{l}^{-1}, 2 \%(\mathrm{w} / \mathrm{v}) \mathrm{SDS}, 25 \mathrm{mmol}$ DTT $\mathrm{l}^{-1}$ by shaking at room temperature for $5 \mathrm{~h}$. The insoluble gel-like material was removed by centrifugation at $10000 \mathrm{~g}$ for $20 \mathrm{~min}$. The protein content was estimated using the Bio-Rad DC protein assay (Bio-Rad Laboratories, Hercules, CA), which is similar to that described by Lowry et al. (1951), but is more tolerant of detergents.

\section{Electron microscopy}

Samples from each step of the isolation procedure were fixed in $2.5 \%(\mathrm{v} / \mathrm{v})$ glutaraldehyde in $0.1 \mathrm{~mol}$ sodium cacodylate $\mathrm{l}^{-1}$ buffer, $\mathrm{pH} 7.4$, overnight at $4^{\circ} \mathrm{C}$, and postfixed in $1 \%(\mathrm{v} / \mathrm{v})$ osmium tetroxide. After dehydration in alcohol, samples were embedded in Epon 812. Thin sections were stained with uranyl acetate and lead citrate, and examined on a Jeol II electron microscope.

\section{SDS-PAGE}

The isolated fibrous sheath was solubilized in $25 \mathrm{mmol}$ Tris- $\mathrm{HCl} \mathrm{l} 1^{-1}, \mathrm{pH} 8,1 \%(\mathrm{w} / \mathrm{v})$ SDS, 2 mmol DTT $1^{-1}$ for $90 \mathrm{~min}$ with shaking at room temperature. The insoluble fraction, composed mainly of a few remaining sperm heads and remnants of the outer dense fibre cortex, were removed by centrifugation. The apparent molecular size of proteins was determined using $12.5 \%(\mathrm{w} / \mathrm{v})$ SDS-polyacrylamide gels (Laemmli, 1970) under reducing conditions; $40-50 \mu \mathrm{g}$ of protein per lane was used for Coomassie brilliant blue staining and $1 \mu \mathrm{g}$ of protein for silver staining with mini gels (Wray et al,, 1981). The molecular size was calibrated using molecular weight standards (Bio-Rad) and densitometry was performed using a LKB 2202 Ultrascan Densitometer (Bromma).

\section{Antibody preparation}

The isolated rat fibrous sheath was solubilized and the insoluble material removed (as described in the previous section) and emulsified 1:1 in Freund's complete adjuvant (Commonwealth Serum Laboratories, Melbourne). New 
Zealand white rabbits were injected s.c. into multiple sites around the neck and shoulders with $1 \mathrm{ml}$ of emulsion containing $75 \mu \mathrm{g}$ fibrous sheath. The rabbits were boosted with $25 \mu \mathrm{g}$ of fibrous sheath in Freund's incomplete adjuvant at intervals of 2 weeks. Serum was collected after each boost and tested using western blotting.

\section{Western blotting}

Approximately $10 \mu \mathrm{g}$ of total sperm protein from rat, rabbit and human together with the purified rat fibrous sheath was run on $12.5 \%(\mathrm{w} / \mathrm{v})$ SDS-PAGE and then transferred onto nitrocellulose membrane (BA 85, Schleicher and Schuell, Dassel) in a $20 \mathrm{mmol}$ Tris $\mathrm{l}^{-1}, 150 \mathrm{mmol}$ glycine $\mathrm{l}^{-1}$ buffer containing $20 \%(\mathrm{v} / \mathrm{v})$ methanol at $60 \mathrm{~V}$ overnight (Towbin et al., 1979). The transfer buffer was then changed to $25 \mathrm{mmol}$ phosphate buffer $\mathrm{l}^{-1}, \mathrm{pH} 6.5,20 \%$ methanol (v/v), and transferred at $30 \mathrm{~V}$ for a further $5 \mathrm{~h}$. The excess protein-binding sites on the membrane were blocked with $0.05 \mathrm{~mol}$ phosphate $1^{-1}$ buffer, $\mathrm{pH} 7.5,0.15 \mathrm{~mol} \mathrm{NaCl} \mathrm{l}^{-1}$ (PBS), containing $1 \%(\mathrm{w} / \mathrm{v})$ non-fat milk powder for $1 \mathrm{~h}$. The membrane was probed overnight at room temperature with a rabbit polyclonal antiserum (JMR 2) raised against whole purified rat fibrous sheath or pre-immune serum diluted 1:1000 with PBS containing 1\% (v/v) Tween 20 (Sigma, St Louis, MO). The membrane was then incubated for $3 \mathrm{~h}$ with a biotinylated sheep antirabbit immunoglobulin antiserum (Silenus Laboratories, Melbourne), diluted 1:3000 in PBS-Tween. This was followed by incubation for $1 \mathrm{~h}$ with streptavidin-horse radish peroxidase (Silenus) diluted 1:8000 in PBS-Tween. The blot was developed with $10 \mathrm{mg} \mathrm{3,3^{ \prime } -}$ diaminobenzidine (DAB, Sigma) diluted in $15 \mathrm{ml}$ of $20 \mathrm{mmol}$ Tris $-\mathrm{HCl} \mathrm{l}^{-1}, \mathrm{pH} \mathrm{7.5,0.15} \mathrm{mol} \mathrm{NaCl}^{-1}$.

\section{Isolation of fibrous sheath protein components}

Individual proteins were isolated with a high degree of purity by cutting out the bands lightly stained with Coomassie brilliant blue from a $12.5 \%$ reduced SDS-PAGE gel and performing electroelution (Hunkapiller et al., 1983) to recover the proteins from the gel. The purity of the bands was determined by SDS-PAGE and silver staining. Protein recovery was determined by the Bio-Rad DC protein assay and by amino acid analysis. The samples were stored at $-20^{\circ} \mathrm{C}$.

\section{Amino acid analysis}

Samples for amino acid analysis were precipitated with 8 volumes of $100 \%$ cold methanol $\left(-20^{\circ} \mathrm{C}\right)$; the precipitate was resuspended in $20 \mathrm{ml}$ of water and precipitated for a second time with cold methanol. The samples were then lyophilized and hydrolysed in a vacuum in constantly boiling $6 \mathrm{~mol} \mathrm{HCl}$ $\mathrm{I}^{-\mathrm{I}}$ containing $0.2 \%(\mathrm{w} / \mathrm{v})$ phenol for $22 \mathrm{~h}$ at $110^{\circ} \mathrm{C}$. Samples were then analysed using the Millipore Picotag method (Millipore, Bedford, MA; Cohen and Strydom, 1988). The losses incurred by the hydrolysis, as measured in control proteins, were minimal (Stanton et al., 1992) except for tyrosine (26\%). Methionine and cystine (including cysteine) content was estimated by oxidizing the samples to methionine sulphone and cysteic acid, respectively, using performic acid. Samples were analysed at least twice in separate hydrolysates and the results averaged. The average coefficient of variation between runs was less than $2 \%$.

\section{Amino-terminal sequencing}

Proteins were sequenced for five cycles and amino acids identified by an online Applied Biosystems 470A gas phase sequencer (Applied Biosystems Inc, Foster, CA). Isolated abundant proteins $(80.9 \mathrm{kDa} ; 28.5 \mathrm{kDa})$ were applied directly or proteins from solubilized fibrous sheath $(80.9 \mathrm{kDa}, 28.5 \mathrm{kDa}$, $32.7 \mathrm{kDa}$ and $15.5 \mathrm{kDa}$ ) were transferred to PVDF membrane (Immobilon-PSQ, Millipore Corp, Bedford, MA).

\section{Immunofluorescence microscopy}

Rat cauda epididymal spermatozoa and ejaculated rabbit and human spermatozoa were washed in PBS-PMSF, and then spotted on glass slides precoated with poly-L-lysine and fixed with $2 \%(\mathrm{v} / \mathrm{v})$ formaldehyde for $30 \mathrm{~min}$ at $4^{\circ} \mathrm{C}$, and then processed for indirect immunofluorescence as described by Almahbobi and Hall (1993). In brief, the attached spermatozoa were extracted with $1 \%(\mathrm{v} / \mathrm{v})$ Triton $\mathrm{X}-100$ in $10 \mathrm{mmol}$ Pipes $1^{-1}, \mathrm{pH} 6.8,0.1 \mathrm{~mol} \mathrm{NaCl} \mathrm{l}^{-1}, 3 \mathrm{mmol} \mathrm{MgCl}_{2} \mathrm{l}^{-1}, 20 \%$ (w/v) sucrose, for $5 \mathrm{~min}$ at $4^{\circ} \mathrm{C}$. Nonspecific binding and autofluorescence were reduced by treating the spermatozoa with $1.5 \%$ $(\mathrm{w} / \mathrm{v})$ glycine for $20 \mathrm{~min}$ and $1 \%(\mathrm{w} / \mathrm{v})$ sodium borohydride for $30 \mathrm{~min}$. The spermatozoa were then incubated with the antifibrous sheath antiserum (JMR 2), diluted 1:100 for $60 \mathrm{~min}$, and then with sheep anti-rabbit immunoglobulin conjugated to fluorescein isothiocyanate (Silenus, Melbourne; 1:50) for $30 \mathrm{~min}$. Nonspecific staining was determined by replacing the primary antiserum with preimmune rabbit serum or with PBS. Autofluorescence and aldehyde-induced fluorescence were tested by omitting the second antibody before and after fixation. Photography and printing were performed at the same settings.

\section{Results}

\section{Isolation of fibrous sheath}

Extraction of isolated cauda epididymal spermatozoa in Triton X-100 and DTT completely solubilized the plasma membrane and mitochondrial sheath. The outer dense fibres of the middle piece were exposed, while the fibrous sheath of the principal piece remained intact. The microtubules of the axoneme were disrupted, as shown in Fig. 1a. After extraction with urea and DTT, the disrupted axoneme and most of the outer dense fibres were solubilized; however, some remnants of the outer dense fibre cortex remained in the isolated fibrous sheath preparation (Fig. Ib). The yield from each experiment (12 rats) was $2.9 \pm 0.4 \mathrm{mg}$ of fibrous sheath protein, as estimated by amino acid analysis.

\section{SDS-PAGE}

SDS-PAGE of isolated fibrous sheath proteins revealed at least 17 bands stained by Coomassie brilliant blue (Fig. 2a) 


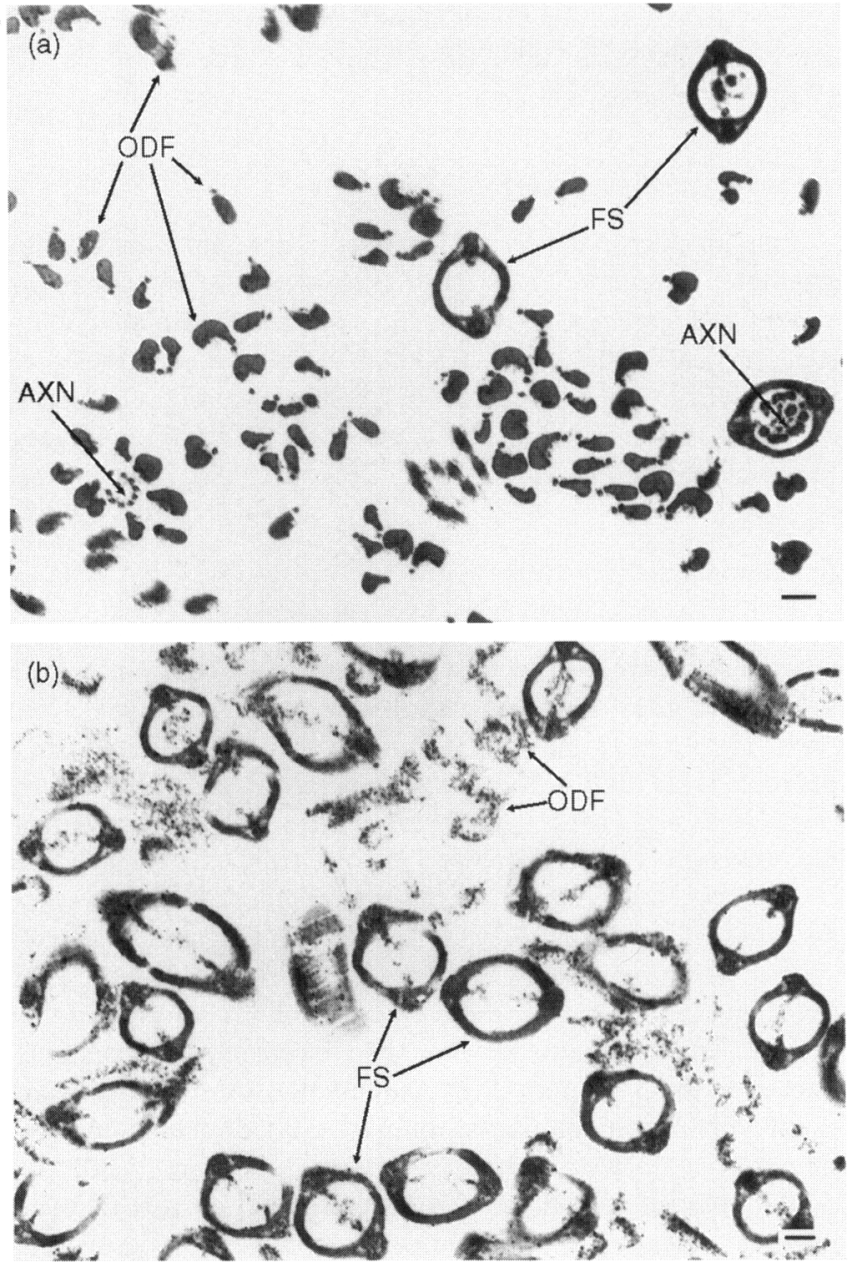

Fig. 1. Electron micrographs showing the effect of the chemical dissection used in the isolation of fibrous sheath. (a) Cross-sections of the middle and the principal piece of the flagella after treatment with Triton X-100 and DTT. The plasma membrane and mitochondrial sheath were solubilized exposing the outer dense fibres (ODF), the fibrous sheath (FS), and the axoneme (AXN). (b) Cross-sections after further treatment with urea and DTT. The axoneme and most of the outer dense fibres were solubilized. Remnants of outer dense fibres, mostly the cortex portion (ODF) remained. Note that the fibrous sheath (FS) remained intact. Scale bars represent $200 \mathrm{~nm}$.

and 20 different major and minor proteins by silver staining (Fig. 2b). The most intensely stained proteins were the double band at $80-87 \mathrm{kDa}$, and the $28.5 \mathrm{kDa}$ band using both staining methods, whereas the $66.2 \mathrm{kDa}$ and $32.7 \mathrm{kDa}$ bands were apparently abundant only using silver staining. In contrast, the apparent abundance of the $15.5 \mathrm{kDa}$ protein was greater with Coomassie brilliant blue staining than with silver staining. The densitometry profile of total fibrous sheath protein in a silver stained gel indicates that the $80-87 \mathrm{kDa}$ band is composed of at least three protein species. The relative quantities of the ten most abundant proteins, as calculated from densitometry (Fig. 3) of a silver stained gel, are shown in Table 1 . The $80-87 \mathrm{kDa}$ proteins account for almost half the protein composition and, together with the $28.5 \mathrm{kDa}$ and $32.7 \mathrm{kDa}$ proteins, make up $88 \%$ of the rat fibrous sheath protein components.

\section{Isolation of fibrous sheath protein components}

Electroelution was followed by SDS-PAGE, and ten of the fibrous sheath proteins were isolated (Fig. 2c). The $15.5 \mathrm{kDa}$ protein was also isolated; however, due to its low yield and poor silver staining property, this protein did not show sufficient intensity to be photographed. The yield of these highly purified proteins is shown in Table 1 . The total yield of the combined proteins was $62.34 \pm 1.97 \mu \mathrm{g}$ for the 12 rats, which represents $2.1 \%$ of the total protein in the isolated fibrous sheath. This yield was low considering that the purification involved only a two-step procedure. Other means of purification such as reverse phase, ion exchange and gel filtration chromatography were unsuccessful in separating the individual proteins. The yields of each protein were disproportionate to their abundance in the original material (Table 1 ). The $28.5 \mathrm{kDa}$ protein had the highest yield of recovered protein; however, this was only $2.9 \%$ of the total amount of the $28.5 \mathrm{kDa}$ protein present. The most abundant proteins $(87.5-$ $80 \mathrm{kDa}$ ) had a yield of only $0.5 \%$ of the available protein. Other proteins had high yield, such as the $116 \mathrm{kDa}$ protein; the $37.3 \mathrm{kDa}$ protein, which was almost undetectable, yielded $4.12 \mu \mathrm{g}$.

\section{Amino acid analysis}

Amino acid composition of whole fibrous sheath is shown in Table 2, and is characterized by high values for aspartic acid (representing aspartic acid and asparagine) and glutamic acid (representing glutamic acid and glutamine). Serine, leucine and cystine (representing cysteine and cystine) were abundant and there was a low content of histidine, phenylalanine and isoleucine.

The amino acid compositions of the 11 purified proteins (Table 2) were also characteristically high in aspartic and glutamic acid, although the $15.5 \mathrm{kDa}$ protein contained less aspartic acid $(5.8 \%)$ and the $32.7 \mathrm{kDa}$ protein contained the least glutamic acid $(6.8 \%)$. Although the amino acid compositions of all 11 proteins were similar, there were, in most proteins, some differences that were above the $2 \%$ reproducibility. This finding suggests that most, if not all, of the proteins are unique rather than fragments of different sizes from a parent protein. The content of cystine varied widely between the different molecular mass species, from $9.4 \%$ in the $46.8 \mathrm{kDa}$ to $1.4 \%$ in the $80.9 \mathrm{kDa}$ and $49.7 \mathrm{kDa}$ species. The loss of tyrosine on hydrolysis was high when estimated in standard proteins in our system (Stanton et al., 1992); however, three of the isolated proteins, $49.7 \mathrm{kDa}, 37.3 \mathrm{kDa}$ and $32.7 \mathrm{kDa}$, had a high content of tyrosine, compared with the other proteins. Attempts to sequence the $80 \mathrm{kDa}, 32.7 \mathrm{kDa}, 28.5 \mathrm{kDa}$ and $15.5 \mathrm{kDa}$ proteins were unsuccessful, presumably owing to blocking of the amino terminus.

\section{Sperm proteins}

SDS-PAGE of solubilized proteins from human, rabbit and rat spermatozoa are compared with that of isolated rat fibrous sheath (Fig. 4). Protein bands of similar staining intensity were seen corresponding to $116 \mathrm{kDa}, 80-87 \mathrm{kDa}, 57.2 \mathrm{kDa}$ 
(a)

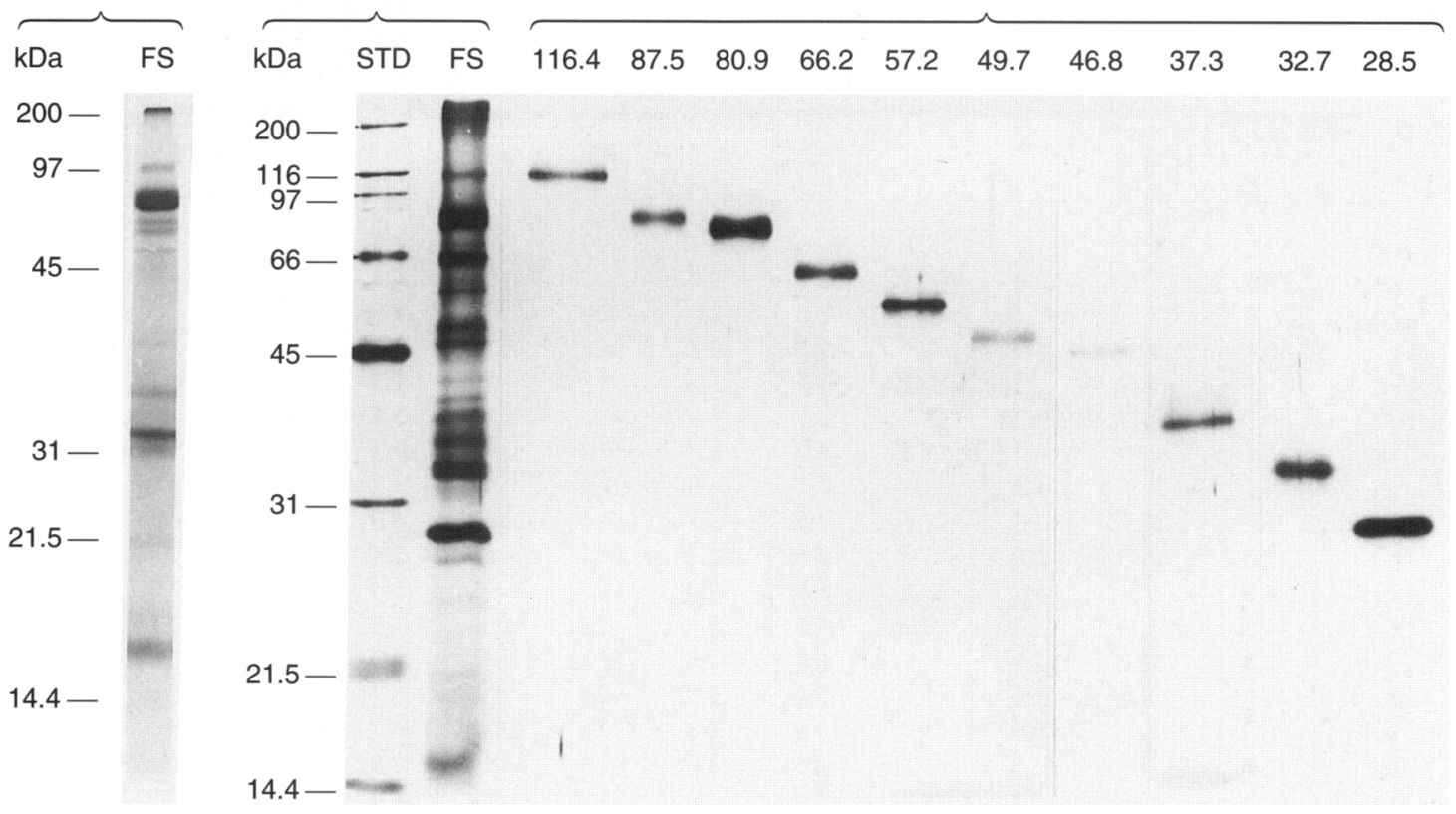

Fig. 2. SDS-PAGE using $12.5 \%$ gels of rat total fibrous sheath proteins (FS) stained with (a) Coomassie brilliant blue and (b) silver stain. These are compared with the isolated individual proteins (c) which were also silver stained. The apparent molecular size of each isolated protein is given in $\mathrm{kDa}$. STD: standards.

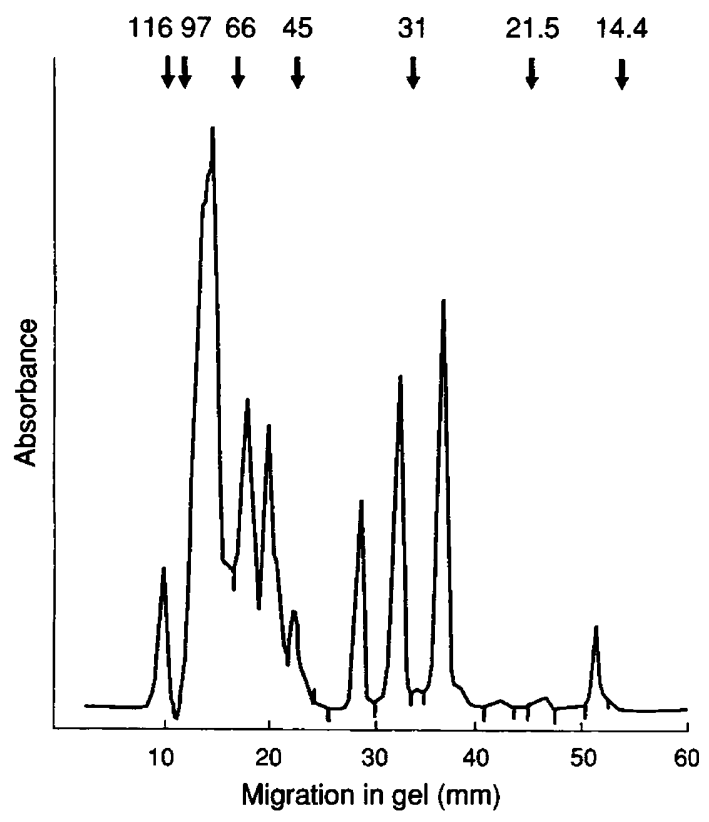

Fig. 3. Densitometry profile of silver stained SDS-PAGE of the isolated total rat fibrous sheath, showing two leading shoulders on the peak in the $80-90 \mathrm{kDa}$ region, suggesting at least three proteins that have a similar molecular mass. The positions of the molecular mass standards $(\mathrm{kDa})$ are marked with arrows.

$32.7 \mathrm{kDa}, 28.5 \mathrm{kDa}$ and $15.5 \mathrm{kDa}$, although some speciesspecific bands of different molecular masses were present. Western blot analysis of isolated rat fibrous sheath with immune serum raised against purified rat fibrous sheath showed
Table 1. The abundance and yields of the isolated rat fibrous sheath proteins from the cauda epididymides of 12 rats

\begin{tabular}{lccr}
\hline $\begin{array}{l}\text { Protein band } \\
(\mathrm{kDa})\end{array}$ & $\begin{array}{c}\text { Total protein } \\
(\%)\end{array}$ & $\begin{array}{c}\text { Yield } \\
(\mu \mathrm{g})\end{array}$ & $\begin{array}{c}\text { Yield } \\
(\%)\end{array}$ \\
\hline 116.4 & 2.0 & $5.14 \pm 0.55$ & 8.8 \\
87.5 & $\mathrm{nd}^{\mathrm{a}}$ & $1.57 \pm 0.40$ & \\
80.0 & 48.6 & $5.87 \pm 1.49$ & 0.5 \\
66.2 & 2.7 & $4.39 \pm 0.05$ & 5.6 \\
57.2 & 2.9 & $6.32 \pm 2.40$ & 7.5 \\
49.6 & 0.8 & $3.38 \pm 1.11$ & 14.4 \\
46.8 & 2.4 & $1.61 \pm 0.31$ & 2.3 \\
37.3 & $\mathrm{nd}$ & $4.12 \pm 2.04$ & \\
32.7 & 10.6 & $3.49 \pm 0.66$ & 1.1 \\
28.5 & 28.7 & $24.09 \pm 12.55$ & 2.9 \\
15.5 & 1.3 & $2.35 \pm 0.07$ & 6.2 \\
Total & 100 & $62.34 \pm 1.97$ & 2.1 \\
& & & \\
\hline
\end{tabular}

${ }^{a}$ Detected as part of the $80-87$ band.

bUnresolved by densitometry.

crossreactivity with fibrous sheath proteins, corresponding to their apparent abundance on SDS-PAGE gels. The $116 \mathrm{kDa}$ and $80 \mathrm{kDa}$ polypeptides of the rat, rabbit and human sperm proteins were strongly immunoreactive. The rat and rabbit sperm proteins had similar immunoreactive proteins of $80-87 \mathrm{kDa}, 57.2 \mathrm{kDa}, 32.7 \mathrm{kDa}$ and $28.5 \mathrm{kDa}$; however, there was no immunoreactivity or weak immunoreactivity with the rest of the human sperm proteins. The preimmune serum did not crossreact with any bands. 
Table 2. Amino acid composition of the rat fibrous sheath protein (FS) and the isolated protein components identified by apparent molecular mass $(\mathrm{kDa})$

\begin{tabular}{|c|c|c|c|c|c|c|c|c|c|c|c|c|}
\hline & \multirow[b]{2}{*}{ FS } & \multicolumn{11}{|c|}{ Apparent molecular mass ( $\mathrm{kDa})$} \\
\hline & & 116.4 & 87.5 & 80.9 & 66.2 & 57.2 & 49.7 & 46.8 & 37.3 & 32.7 & 28.5 & 15.5 \\
\hline Asp & 10.1 & 11.1 & 11.8 & 15.3 & 13.6 & 10.1 & 13.9 & 11.5 & 8.8 & 8.0 & 11.1 & 5.8 \\
\hline Glx & 12.3 & 11.7 & 10.9 & 12.6 & 10.9 & 9.0 & 11.2 & 10.5 & 9.3 & 6.8 & 11.6 & 9.0 \\
\hline Ser & 8.8 & 7.6 & 7.4 & 7.7 & 5.6 & 5.6 & 5.9 & 6.6 & 5.5 & 6.0 & 5.6 & 7.3 \\
\hline Gly & 5.8 & 8.8 & 8.9 & 7.8 & 7.8 & 9.2 & 8.8 & 11.4 & 8.3 & 9.6 & 6.0 & 11.3 \\
\hline $\mathrm{His}$ & 1.5 & 1.4 & 1.3 & 3.3 & 1.6 & 3.2 & 1.1 & 1.1 & 1.3 & 1.2 & 1.3 & 1.2 \\
\hline Arg & 4.7 & 3.7 & 4.2 & 3.1 & 3.9 & 3.7 & 3.3 & 3.1 & 3.2 & 4.0 & 4.7 & 7.0 \\
\hline Thr & 3.8 & 4.9 & 4.0 & 3.1 & 3.7 & 4.3 & 3.4 & 3.4 & 3.2 & 4.6 & 3.6 & 6.0 \\
\hline Ala & 6.1 & 9.3 & 8.2 & 8.9 & 7.1 & 8.3 & 7.4 & 4.7 & 8.2 & 9.1 & 6.0 & 10,3 \\
\hline Pro & 5.9 & 5.8 & 2.3 & 4.5 & 7.3 & 6.1 & 4.6 & 4.1 & 6.0 & 4.9 & 4.5 & 6.5 \\
\hline Tyr & 2.0 & 0.5 & 0.6 & 0.9 & 4.6 & 1.1 & 11.1 & 4.1 & 8.4 & 7.1 & 1.4 & 0.6 \\
\hline Val & 4.8 & 6.3 & 5.7 & 5.2 & 6.9 & 7.0 & 4.7 & 5.5 & 6.9 & 6.7 & 3.3 & 6.0 \\
\hline Met & 4.3 & 2.2 & 3.2 & 3.0 & 3.3 & 5.7 & 2.8 & 3.0 & 5.9 & 3.5 & 3.5 & 1.2 \\
\hline Cys & 8.8 & 4.3 & 7.5 & 1.4 & 3.4 & 1.6 & 1.4 & 9.4 & 3.3 & 4.3 & 8.4 & 4.8 \\
\hline Ile & 3.2 & 4.4 & 5.0 & 4.1 & 4.8 & 6.9 & 4.8 & 5.5 & 5.1 & 5.4 & 4.6 & 4.9 \\
\hline Leu & 8.5 & 8.7 & 8.9 & 8.7 & 6.8 & 8.8 & 7.4 & 7.2 & 8.1 & 7.8 & 10.6 & 9.4 \\
\hline Phe & 2.2 & 3.7 & 1.8 & 2.1 & 2.6 & 3.0 & 2.2 & 2.9 & 2.5 & 3.3 & 6.1 & 1.6 \\
\hline Lys & 7.1 & 5.8 & 8.3 & 8.5 & 6.1 & 6.5 & 5.9 & 5.9 & 6.1 & 7.6 & 7.7 & 7.0 \\
\hline
\end{tabular}

(a)

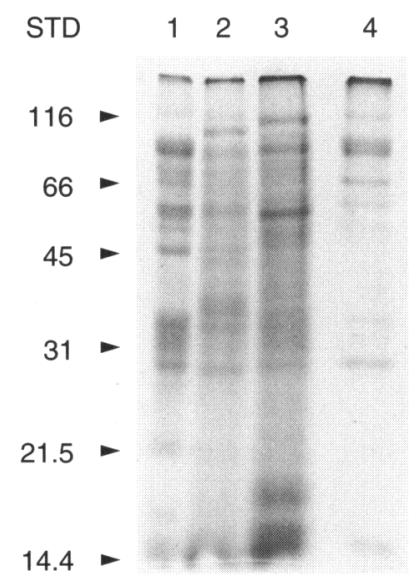

(b)

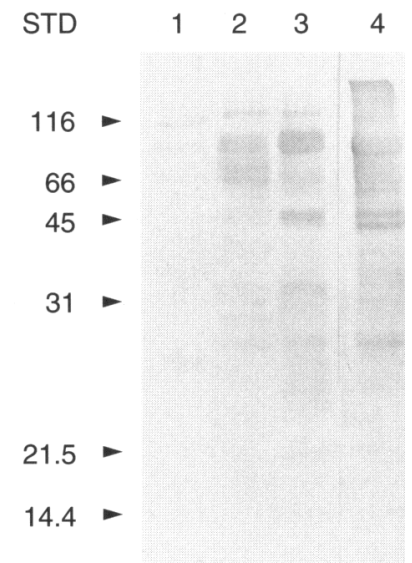

Fig. 4. (a) SDS-PAGE of solubilized (1) rat, (2) rabbit, and (3) human spermatozoa together with (4) isolated total fibrous sheath stained with Coomassie brilliant blue. (b) Western blot of (1) human, (2) rabbit and (3) rat spermatozoa, and (4) isolated rat fibrous sheath, probed with a polyclonal antibody against rat fibrous sheath. STD: standards.

\section{Immunofluorescence microscopy}

Positive staining with the antiserum was confined to the principal piece of rat spermatozoa (Fig. 5b) since, as monitored by phase-contrast microscopy (Fig. 5a), the head showed no sign of staining. All the controls showed complete negative staining throughout the whole structure of the spermatozoa (Fig. 5d). The fluorescent signal seen within the middle piece was due to neither crossreactivity of the antibody nor nonspecific binding, since these signals were always detected in this region without the addition of the second antibody, indicating an autofluorescent property. Specific staining was
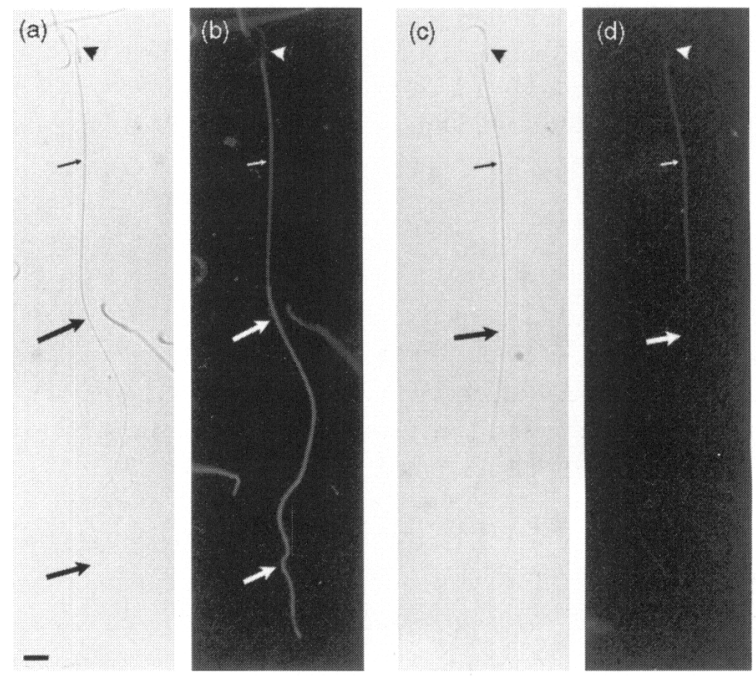

Fig. 5. Immunofluorescence localization of rat fibrous sheath proteins. Phase-contrast $(a, c)$ and fluorescence $(b, d)$ micrographs of the same fields of rat spermatozoa probed with an anti-rat fibrous sheath antiserum raised in rabbits $(a, b)$, or preimmune rabbit serum $(c, d)$. Positive staining is shown mainly in the principal piece of the spermatozoa (large arrows). Small arrows indicate the middle piece where the autofluorescence is clear in (b) and (d). The principal piece shows no staining in control (d) and no crossreactivity is seen in the sperm head (arrowheads). Scale bar represents $7 \mu \mathrm{m}$.

also seen exclusively in the principal piece of human and rabbit spermatozoa (Figs $6 \mathrm{~b}$ and d, respectively). The antiserum also showed crossreactivity in the equatorial segment of rabbit sperm heads. All controls displayed the same phenomenon of autofluorescence in the middle piece (Fig. 6e; data for rabbit spermatozoa not shown) as did the rat spermatozoa. 

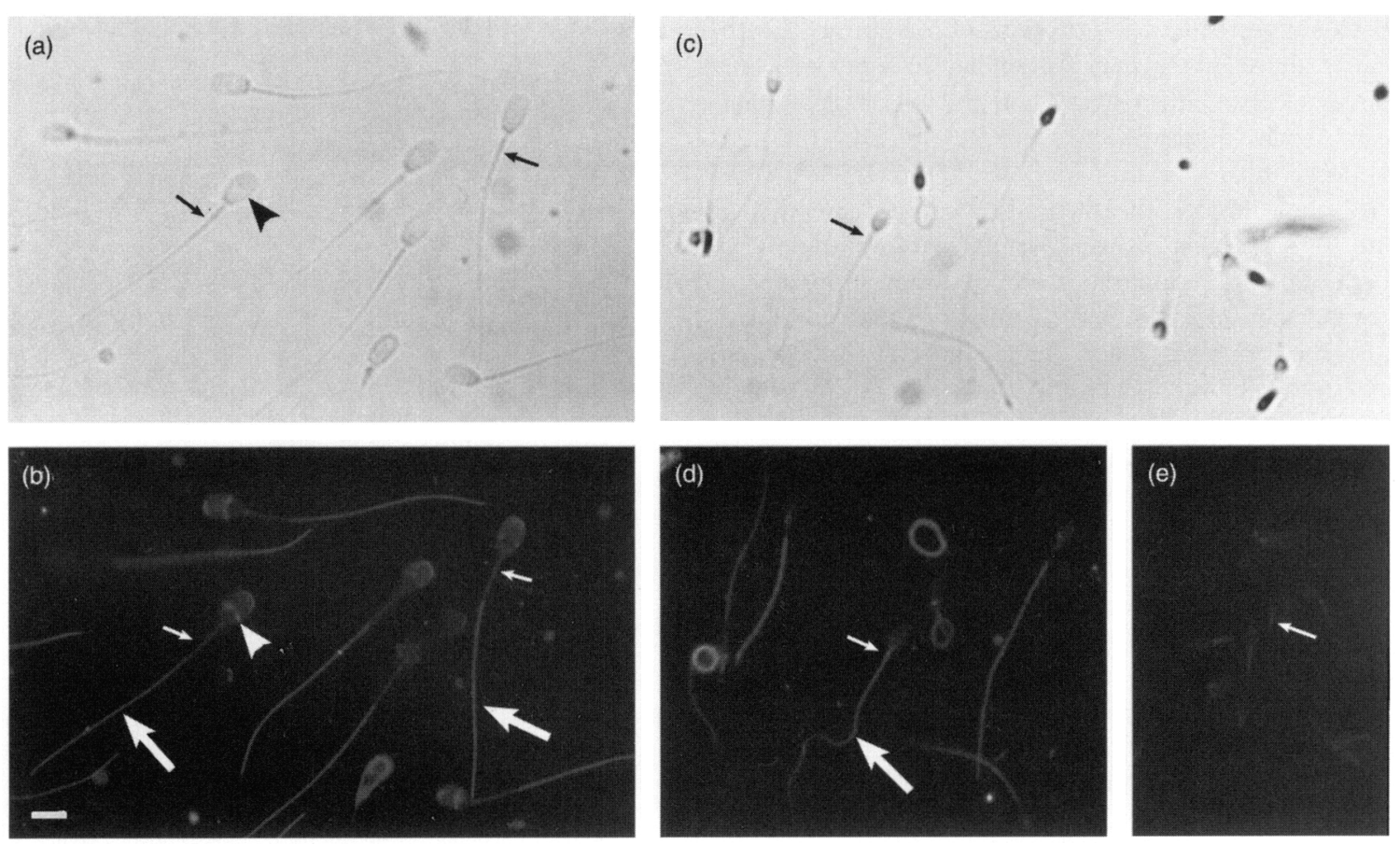

Fig. 6. Immunofluorescence localization of rabbit and human fibrous sheath proteins. Phase-contrast $(a, c)$ and fluorescence $(b, d, e)$ micrographs of the same fields of rabbit $(a, b)$ and human $(c, d, e)$ spermatozoa probed with a rabbit anti-rat fibrous sheath antiserum. No fluorescein isothiocyanate-conjugated second antibody was used in panel (e). In both species, immunostaining is seen only in the principal piece (large arrows), while the middle piece shows only an autofluorescent background (small arrows). Specific staining is also seen in the equatorial region of the rabbit sperm head (arrowheads). Scale bar represents $7 \mu \mathrm{m}$.

\section{Discussion}

This study demonstrates that it is possible to isolate a large number of the individual proteins that compose the fibrous sheath of the rat sperm tail. Other studies have isolated the fibrous sheath and separated its individual components by gel electrophoresis (Olson et al., 1976; Oko, 1988) but only Brito et al. (1989) have been able to isolate sufficient quantities of three of these components to obtain amino acid analysis. Our data confirm these findings and extend the number of components that can be isolated using two biochemical procedures combined with several physicochemical separation techniques. Although the losses during the electroelution step are large, the process does enable isolation of sufficient quantities for amino acid analysis and attempts at amino-terminal sequencing. The latter technique has not yielded any sequences to date due to amino-terminal blocking of the $80 \mathrm{kDa}, 32.7 \mathrm{kDa}, 28.5 \mathrm{kDa}$ and $15.5 \mathrm{kDa}$ proteins. Attempts to use gel filtration, ion exchange or reverse phase HPLC were unsuccessful in purifying these proteins.

Chemical dissection of spermatozoa using SDS, Triton X-100, urea and DTT has been used to characterize various sperm structures by their selective solubilization properties (Millette et al., 1973; Olson et al., 1976; Calvin, 1976; Vera et al., 1984; Oko, 1988; Jassim et al., 1992). In the study reported here, a slight modification of the method developed by Olson et al. (1976) was used. The majority of the sperm tail components was solubilized by treatment with urea and DTT, followed by extraction with Triton X-100 and DTT. Although this treatment left the fibrous sheath intact, remnants of the outer dense fibre cortex remained. This suggests that there is a complex three-dimensional structural organization of the outer dense fibres, with a different protein composition in the cortex from that in the medulla. Contamination by the outer dense fibre in our fibrous sheath preparation was minimized by solubilizing the fibrous sheath in $2 \%$ SDS and DTT, which allowed the removal of the outer dense fibre cortex by centrifugation.

The amino acid composition of the $80 \mathrm{kDa}$ and $24 \mathrm{kDa}$ proteins reported by Brito et al. (1989) are similar to the composition of the $80 \mathrm{kDa}$ and $28.5 \mathrm{kDa}$ proteins in the study reported here. However, the $15.5 \mathrm{kDa}$ protein in this study differs significantly from the $12 \mathrm{kDa}$ protein of Brito et al. (1989), particularly in serine, alanine, tyrosine, valine and isoleucine content. These differences may relate to contamination of the fibrous sheath preparation by the cortex of the outer dense fibre using the preparative scheme outlined. In the study reported here, a further step was introduced to remove this contamination, whereas no comment was made regarding such material in the study by Brito et al. (1989). In addition, data on the amino acid composition of a further six proteins isolated from the fibrous sheath are presented here. It is clear that amino acid sequences are necessary to identify the genes encoding these proteins as a prelude to determining their role in the formation of the fibrous sheath. However, in view of the fact that the amino termini of a number of these proteins were blocked, the amino acid composition provides a method of characterizing some of these proteins. 
It has been suggested that the proteins of the fibrous sheath and the outer dense fibres may be similar in view of their features under electron microscopy and the observation that antibodies to fibrous sheath proteins crossreacted with those in the outer dense fibres in the study by Oko (1988). Our antibody to whole fibrous sheath did not crossreact with the outer dense fibre proteins on western blots (data not shown) and, furthermore, the immunofluorescence localization of the epitopes recognized by the fibrous sheath antiserum were confined to the principal piece of rat, rabbit and human spermatozoa and did not localize to the region of the midpiece. Again, these differences may relate to the purity of the fibrous sheath preparations used to immunize rabbits. The fact that the $116 \mathrm{kDa}$ and $80 \mathrm{kDa}$ proteins of all species crossreact with the antiserum to the rat fibrous sheath raises the possibility that these proteins share common antigenic determinants. Furthermore, additional fibrous sheath proteins common to the rat and rabbit are detected by the antiserum. The equatorial segment of the rabbit sperm head also crossreacted strongly with the antiserum and the reasons for this are unclear. In many species, the equatorial segment exhibits properties that distinguish it from other regions of the head, but it is surprising that a flagella protein or part thereof is represented in this region.

The availability of the antiserum offers the possibility of screening $\lambda$ gt 11 expression libraries with a view to cloning the genes encoding for the proteins that appear to be aminoterminally blocked. Antibodies to fibrous sheath proteins have been described in a number of studies raising the prospect of their use to screen libraries (Sakai et al., 1986; Fenderson et al., 1988; Jassim, 1991; Jassim et al., 1991; Beecher et al., 1993). Alternatively, approaches such as those outlined by Morales et al. (1994), who obtained an internal amino acid sequence of the $27 \mathrm{kDa}$ outer dense fibre protein, may be applicable to the fibrous sheath proteins. The demonstration that it is possible to isolate sufficient quantities of a number of these proteins for amino acid analysis should provide the basis for further studies of their structure.

This study was supported by a grant from the Victorian Health Promotion Foundation. Y. H. Kim was supported by an overseas postgraduate award and a Monash Graduate Scholarship. The authors thank A. Meinhardt for critically reading the manuscript.

\section{References}

Almahbobi G and Hall P (1993) Indirect immunofluorescence modified to display two antigens with one light filter Histochemical Journal 25 14-18

Bedford JM and Calvin HI (1974) Changes in -S-S- linked structures of the sperm tail during epididymal maturation, with comparative observations in sub-mammalian species Journal of Experimental Zoology 187 181-204

Beecher KL, Homyk M, Lee CYG and Herr JC (1993) Evidence that 68-kilodalton and 54-51 kilodalton polypeptides are components of the human sperm fibrous sheath Biology of Reproduction 48 154-164

Brito M, Figueroa J, Maldonado EU, Vera JC and Burzio LO (1989) The major component of the rat sperm fibrous sheath is a phosphoprotein Gamete Research 22 205-217

Calvin HI (1976) Isolation and subfractionation of mammalian sperm heads and tails. In Methods in Cell Biology Vol. XIII pp 85-104 Ed. DM Prescott. Academic Press, New York

Clermont Y, Oko R and Hermo L (1990) Immunocytochemical localization of proteins utilized in the formation of outer dense fibers and fibrous sheath in rat spermatids: an electron microscope study Anatomical Record 227 $447-457$
Cohen SA and Strydom DJ (1988) Amino acid analysis utilising phenylisothiocyanate derivatives Analytical Biochemistry 174 1-16

Eddy EM (1988) The spermatozoon. In The Physiology of Reproduction Vol. I pp 27-68 Eds E Knobil and J Neill. Raven Press, New York

Eddy EM, O'Brien DA, Fenderson BA and Welch JE (1992) Intermediate filamentlike proteins in the fibrous sheath of the mouse sperm flagellum. In The Male Germ Cell: Spermatogonium to Fertilization pp 224-239 Ed. B Robaire. New York Academy of Science, New York

Fawcett DW (1970) A comparative view of sperm ultrastructure Biology of Reproduction Supplement 2 90-126

Fawcett DW (1975) The mammalian spermatozoon Developmental Biology 44 394-436

Fenderson BA, Toshimori K, Muller CH, Lane TF and Eddy EM (1988) Identification of a protein in the fibrous sheath of the sperm flagellum Biology of Reproduction 38 345-357

Hunkapiller MW, Lujan E, Ostrander F and Hood LE (1983) Isolation of microgram quantities of proteins from polyacrylamide gels for amino acid sequence analysis Methods in Enzymology $91227-247$

Irons MJ and Clermont $Y$ (1982) Kinetics of fibrous sheath formation in the rat spermatid American Journal of Anatomy 165 121-130

Jassim A (1991) AJ-p97: a novel antigen of the human sperm tail fibrous sheath detected by a neurofilament monoclonal antibody Journal of Reproductive Immunology 20 15-26

Jassim A, Auger D, Oliver T and Sachs J (1990) GDA-J/F3 Monoclonal antibody as a novel probe for the human sperm tail fibrous sheath and its anomalies Human Reproduction 5 990-996

Jassim A, Gillott DJ and Al-Zuhdi Y (1991) Human sperm tail fibrous sheath undergoes phosphorylation during its development Human Reproduction 6 $1135-1142$

Jassim A, Gillott DJ, Al-Zuhdi Y, Gray A, Foxon R and Bottazzo GF (1992) Isolation and biochemical characterization of the human sperm tail fibrous sheath Human Reproduction 7 86-94

Laemmli UK (1970) Cleavage of structural proteins during assembly of the head of bacteriophage $T_{4}$ Nature 227 680-685

Lowry OH, Rosebrough NJ, Farr AL and Randall RJ (1951) Protein measurement with the Folin phenol reagent Journal of Biological Chemistry 193 265-275

Millette CF, Spear PG, Gall WE and Edelman GM (1973) Chemical dissection of mammalian spermatozoa Journal of Cellular Biology 58 662-675

Morales CR, Oko R and Clermont Y (1994) Molecular cloning and developmental expression of an mRNA encoding the $27 \mathrm{kDa}$ outer dense fiber protein of rat spermatozoa Molecular Reproduction and Development 37 229-240

O'Brien DA and Bellve AR (1980) Protein constituents of the mouse spermatozoa II. Temporal syntheses during spermatogenesis Developmental Biology $75405-418$

Oko R (1988) Comparative analysis of proteins from the fibrous sheath and outer dense fibers of rat spermatozoa Biology of Reproduction 39 169-182

Oko R and Clermont Y (1989) Light microscopic immunocytochemical study of fibrous sheath and outer dense fiber formation in the rat spermatid Anatomical Record 225 46-55

Olson GE, Hamilton DW and Fawcett DW (1976) Isolation and characterization of the fibrous sheath of rat epididymal spermatozoa Biology of Reproduction 14 517-530

Sakai Y, Koyama YI, Fujimoto T and Yamashina S (1986) Immunocytochemical study on fibrous sheath formation in mouse spermiogenesis using a monoclonal antibody Anatomical Record 215 119-126

Sapsford CS, Rae CA and Cleland KW (1970) Ultrastructural studies on the development and form of the principal piece sheath of the bandicoot spermatozoon Australian Journal of Zoology 188 21-48

Stanton PG, Robertson DM, Burgon PG, Schmauk-White B and Hearn MTW (1992) Isolation and physicochemical characterization of human folliclestimulating hormone isoforms Endocrinology 130 2820-2832

Towbin H, Staehelin T and Gordon J (1979) Electrophoretic transfer of proteins from polyacrylamide gels to nitrocellulose sheets: procedure and some applications Proceedings of National Academy Sciences USA 76 $4350-4354$

Vera JC, Brito M, Zuvic T and Burzio LO (1984) Polypeptide composition of rat sperm outer dense fibers Journal of Biological Chemistry 259 5970-5977

Wray W, Boulikas T, Wray VP and Hancock R (1981) Silver staining of proteins in polyacrylamide gels Analytical Biochemistry 118 197-203 